\title{
Effect of phosphorus and sulphur levels on yield, fractions of phosphorus and sulphur and nitrate reductage activity of soil after harvest of soybean
}

\author{
SHUBHANGI J. DHAGE, V.D. PATIL AND A.L. DHAMAK
}

Received : 23.09.2014; Revised : 09.11.2014; Accepted : 26.11 .2014

\author{
MEMBERS OF RESEARCH FORUM: \\ Corresponding author : \\ SHUBHANGI J. DHAGE, Department \\ of Soil Science and Agricultural \\ Chemistry, Marathwada Krishi \\ Vidyapeeth, PARBHANI (M.S.) INDIA \\ Co-authors : \\ V.D. PATIL AND A.L. DHAMAK, \\ Department of Soil Science and \\ Agricultural Chemistry, Marathwada \\ Krishi Vidyapeeth, PARBHANI (M.S.) \\ INDIA
}

\section{Summary}

A field experiments were conducted to study the effect of phosphorus and sulphur levels on yield, fractions of $\mathrm{P}$ and $\mathrm{S}$ and nitrate reductase activity of soil after harvest of soybean at Research Farm, Department of Soil Science and Agril. Chemistry, MKV, Parbhani (M.S.). The treatment consisted of four levels $\mathrm{P}\left(\mathrm{P}_{0}, \mathrm{P}_{30}, \mathrm{P}_{60}\right.$ and $\left.\mathrm{P}_{90} \mathrm{~kg} \mathrm{P}_{2} \mathrm{O}_{5} \mathrm{ha}^{-1}\right)$ and four levels of $\mathrm{S}\left(\mathrm{S}_{0}, \mathrm{~S}_{20}, \mathrm{~S}_{40}\right.$ and $\left.\mathrm{S}_{60} \mathrm{~kg} \mathrm{ha}^{-1}\right)$ applied through DAP and elemental sulphur. Result indicated that grain and straw yield, Leghaemoglobin content from root nodules at 30 DAS and nitrate reductage activity of soil after harvest of soybean increased with increase in rate of application of $\mathrm{P}$ and $\mathrm{S}$. The applied S and P increased the P and S fractions over control.

Key words : Nitrate reductase activity, Phosphorus, Sulphur, Soybean, Yield

How to cite this article : Dhage, Shubhangi J., Patil, V.D. and Dhamak, A.L. (2014). Effect of phosphorus and sulphur levels on yield, fractions of phosphorus and sulphur and nitrate reductage activity of soil after harvest of soybean. Asian J. Soil Sci., 9(2): 289-293. 